\title{
KLASIFIKASI MODULASI DIGITAL MENGGUNAKAN KOMBINASI TEKNIK FUZZY CLUSTERING DAN TEMPLATE MATCHING SEBAGAI PENGENALAN POLA
}

\author{
Anggun Fitrian Isnawati \\ Program Studi Teknik Telekomunikasi, STT Telematika Telkom Purwokerto \\ Jl. D.I Panjaitan No. 128 Purwokerto, Telp: (0281) 641629 \\ anggun@stttelematikatelkom.ac.id
}

\begin{abstract}
ABSTRAK
Sebagian besar pendekatan untuk pengenalan dan klasifikasi modulasi telah didirikan pada komponen sinyal termodulasi. Dalam tulisan ini, akan dikembangkan algoritma untuk klasifikasi modulasi menggunakan teknik clustering Fuzzy C. Means (FCM) yang mempertimbangkan konstelasi sinyal yang diterima untuk mengidentifikasi jenis modulasi yang dipakai pada komunikasi nirkabel. Identifikasi pola menggunakan template matching dan diperoleh hasil dengan tingkat kecocokan yang tinggi pada semua tipe modulasi yang digunakan. Keywords - klasifikasi, modulasi, clustering, FCM, konstelasi
\end{abstract}

\section{PENDAHULUAN}

Klasifikasi Modulasi (Modulation Classification - MC) merupakan subjek penting dalam militer dan aplikasi komunikasi komersial. Ini adalah masalah yang menantang, terutama di lingkungan yang non-kooperatif. Tujuan klasifikasi modulasi adalah untuk mengidentifikasi jenis modulasi dari komunikasi sinyal. Hal ini berperan penting dalam banyak aplikasi komunikasi seperti perangkat lunak radio, modem cerdas, dan sistem pengawasan elektronik. Dalam banyak situasi komunikasi militer seperti pengintaian, pengawasan dan elektronik peperangan, suatu langkah yang sangat diperlukan adalah untuk mengklasifikasikan secara otomatis jenis modulasi dari sinyal yang diterima [1].

Pengenalan modulasi otomatis memainkan peran penting dalam bidang sipil seperti identifikasi gangguan dan manajemen spektrum. Pengenalan jenis modulasi dari sinyal yang tidak diketahui memberikan pemahaman yang berharga mengenai struktur, asal dan sifatsifatnya. Klasifikasi otomatis modulasi digunakan untuk spektrum pengawasan dan manajemen,

identifikasi gangguan, evaluasi ancaman militer, sumber identifikasi dan banyak lainnya. Misalnya, jika jenis modulasi sinyal dicegat dan diekstrak. Aplikasi lain mungkin termasuk identifikasi sinyal sumber. Hal ini terutama berlaku untuk komunikasi nirkabel di mana berbagai layanan mengikuti standar modulasi yang sudah terkenal. Ada lagi penggunaan untuk aplikasi perkotaan dan militer dan barubaru ini telah menarik banyak perhatian yang memungkinkan untuk membangun Intelligent penerima yang dapat mengenali jenis modulasi tanpa mengetahui informasi terlebih dahulu dari sinyal transmisi. Demikian cerdas pemancarpenerima tampaknya dapat memilih jenis modulasi yang paling tepat untuk mengirimkan informasi karena kondisi lingkungan dan saluran komunikatif, dan juga penerima dapat mengenali perubahan jenis modulasi segera. Oleh karena itu, dalam subjek komunikasi, transparansi dikembangkan karena jenis modulasi. 
Modulasi adalah suatu proses penumpangan sinyal yang hendak dikirim pada sebuah sinyal carrier. Sinyal data dapat ditumpangkan ke sinyal carrier dengan cara mengubah amplitudo, frekuensi, atau fase dari sinyal carrier tersebut. Untuk mendapatkan laju pengiriman data yang lebih besar, dapat pula dilakukan perubahan terhadap kombinasi dari beberapa parameterparameter tersebut, misalnya dengan mengubah amplitudo dan fasenya sekaligus. Untuk pengiriman data melalui frekuensi voiceband, teknik yang biasanya digunakan adalah teknik modulasi digital multisimbol. Teknik modulasi digital multisimbol ada beberapa macam, di antaranya adalah MPSK (Multi-Phase Shift Keying) dan QAM (Quadrature Amplitude Modulation). Modulasi digital multisimbol menawarkan kecepatan yang lebih tinggi karena setiap simbol yang dikirimkan melambangkan beberapa bit sekaligus. Untuk mendapat data rate yang tinggi pada bandwidth yang terbatas biasanya digunakan QAM. Modulasi QAM lebih berguna dan efisien dibandingkan yang lain dan hampir berlaku untuk semua modem progresif. Pengenalan modulasi merupakan langkah menengah di jalan menuju pemulihan pesan penuh.

Salah satu metode analisis khas untuk sinyal termodulasi adalah ekstraksi komponen InPhase (I) dan Quad-Phase (Q). Menurut komponen ini, kita dapat melihat sinyal sebagai vektor dalam bidang I - Q yang disebut sebagai diagram konstelasi. Dengan menggunakan sinyal termodulasi konstelasi, klasifikasi modulasi dapat diselidiki sebagai masalah pengenalan pola dan algoritma terkenal pengenalan pola dapat digunakan.

\section{A. Lintasan Sinyal dan Konstelasi}

Salah satu metode terbaik untuk klasifikasi modulasi sinyal adalah penggunaan lintasan sinyal dan konstelasinya. Karena setiap jenis modulasi mempunyai konstelasi unik dan pengenalan lintasan modulasi sinyal dapat dilakukan secara akurat. Pendekatan untuk analisis sinyal termodulasi didasarkan pada ekstraksi in-phase (I) dan quad-phase (Q) komponen dari sinyal, yang diperoleh melalui demodulator yang sesuai. Hal ini memungkinkan melihat sinyal modulasi sebagai vektor dalam I - Q pesawat, yang lintasan diukur disajikan dalam diagram dua dimensi. Dua tipe diagram yang paling umum [2]:

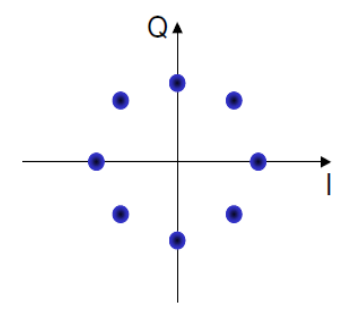

(a)

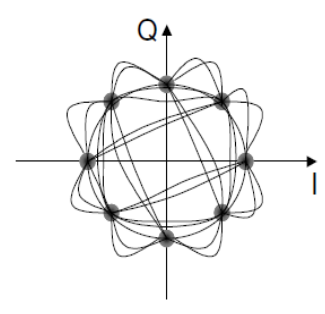

(b)
Gambar. 1 Diagram I-Q (a) Konstelasi (b) Diagram vektor

\section{B. Quadrature Amplitude Modulation (QAM)}

Pada QAM fase dan amplitudo dari sinyal carrier diubah-ubah untuk melambangkan data. Sinyal QAM dapat dituliskan sebagai berikut:

$$
s(t)=I(t) \cdot \cos \omega c t+Q(t) \cdot-\sin \omega c t
$$

dengan:

$$
\begin{aligned}
& \mathrm{I}(\mathrm{t})=\mathrm{A} \cdot \cos \theta \\
& \mathrm{Q}(\mathrm{t})=\mathrm{A} \cdot \sin \theta
\end{aligned}
$$

Dari persamaan (1), dapat dilihat bahwa sinyal QAM dapat dibentuk dengan menjumlahkan sebuah sinyal kosinus dengan amplitudo I(t) dan sebuah sinyal sinus dengan amplitudo $Q(t)$. Ini sama dengan menjumlahkan sebuah sinyal AM (amplitude modulation) yang 
menggunakan carrier cosinus dengan sebuah sinyal AM lain yang menggunakan carrier sinus.

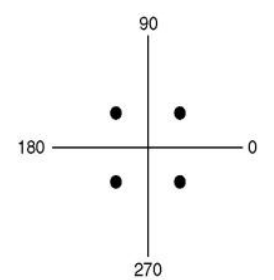

(a)

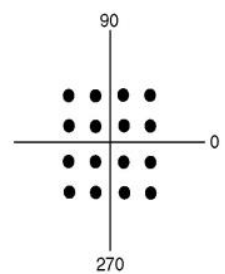

(b)

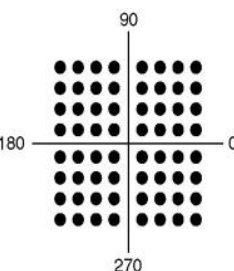

Gambar 2. Diagram Konstelasi (a) 4-QAM (b) 16QAM (c) 64-QAM

Amplitudo dan fase untuk masing-masing simbol pada QAM dapat digambarkan dalam sebuah diagram dua dimensi yang disebut sebagai diagram konstelasi, seperti misalnya diagram konstelasi untuk 16-QAM yang dapat dilihat pada gambar 2. Sumbu x merupakan sumbu yang mewakili cos $\omega c t$ dari persamaan (1) dan disebut sebagai sumbu I (inphase), sedangkan sumbu y adalah sumbu yang mewakili -sinwct dari persamaan (1) dan disebut sebagai sumbu Q (quadrature). Perlu diperhatikan bahwa konfigurasi titik untuk 16QAM tidak selalu seperti diagram konstelasi pada gambar 2 .

Data yang akan dikirim dibagi menurut jumlah bit untuk satu simbol. Setelah itu, data yang telah dibagi dipetakan menurut diagram konstelasi dengan menggunakan mapper. Keluaran dari mapper adalah komponen inphase dan quadrature untuk simbol yang ditentukan oleh data tadi. Kedua komponen ini dijadikan sebagai masukan untuk modulator. Pada penerima, sinyal yang telah dimodulasi perlu dikembalikan ke bentuk semula. Proses ini disebut sebagai proses demodulasi. Rumus untuk demodulator adalah sebagai berikut:

$I^{\prime}(t)=s(t) \cdot \cos \omega c^{\prime} t-\operatorname{sh}(t) \cdot-\sin \omega c^{\prime} t$
$Q^{\prime}(t)=s(t) \cdot-\sin \omega c^{\prime} t+\operatorname{sh}(t) \cdot \cos \omega c^{\prime} t$

Sinyal $s(t)$ adalah sinyal yang diterima sedangkan $\operatorname{sh}(\mathrm{t})$ dihasilkan dengan melakukan Hilbert transform terhadap $\mathrm{s}(\mathrm{t})$. $\omega \mathrm{c}^{\prime}$ adalah frekuensi carrier yang dibangkitkan pada penerima. Hasil dari demodulator dimasukkan ke decision unit yang merupakan unit untuk menentukan simbol yang telah dikirim oleh pemancar dari hasil demodulasi. Decision unit menentukan simbol mana yang sebenarnya dikirim oleh pemancar dengan cara menghitung jarak Euclidean dari titik yang diterima dengan semua titik yang ada pada diagram konstelasi. Simbol yang dipilih adalah simbol yang jaraknya paling kecil dengan titik yang diterima. Keluaran dari decision unit adalah komponen inphase dan quadrature dari titik ideal untuk simbol yang dipilih. Keluaran ini dikembalikan ke dalam bentuk bit-bit oleh unit inverse mapper. Pada proses demodulasi diperlukan carrier lokal yang memiliki frekuensi dan fase yang sama dengan carrier dari sinyal yang diterima. Perbedaan frekuensi carrier pemancar dengan frekuensi carrier penerima dapat terjadi karena adanya perbedaan frekuensi dari oscillator yang digunakan pada pemancar dengan yang digunakan pada penerima. Perbedaan frekuensi dari oscillator disebabkan karena ketidakakuratan pada pembuatannya, perbedaan temperatur, dan lain-lain. Perbedaan fase terjadi terutama pada saat pemancar dan penerima pertama kali dihubungkan dan delay fase pada sinyal yang terjadi pada saluran transmisi.

\section{METODOLOGI PENELITIAN}

\section{A. Alat dan Bahan}


Model simulasi pada penelitian ini menggunakan program MATLAB R2009a.

\section{B. Jalannya Penelitian}

Diagram konstelasi, yang terdiri dari komponen In-fase dan Quad-fase, dapat digunakan untuk klasifikasi modulasi. Karena konstelasi berbentuk simetris terhadap sumbunya, maka untuk mengurangi kompleksitas, dapat dipetakan semua simbol yang diterima ke dalam kuadran pertama di diagram konstelasi. Setelah memperoleh jumlah dan lokasi cluster di kuadran pertama, centroid dari kelompok dapat diperluas ke seluruh konstelasi secara simetris. Teknik yang diusulkan akan dirancang diharapkan mampu mengenali jenis-jenis modulasi digital yaitu: 4QAM, QPSK, 8-PSK, dan 16-QAM. Teknik ini menggunakan Fuzzy Clustering (Fuzzy C Means).

Secara ringkas, langkah-langkah penelitian dalam proses klasifikasi modulasi digital adalah sebagai berikut:

1. Pendefinisian centroid ideal/standar.

Langkah pertama dalam penulisan ini adalah penentuan pola modulasi digital yang akan digunakan yaitu 4-QAM, QPSK, 8-PSK, dan 16-QAM dengan cara mendefinisikan terlebih dahulu centroid ideal untuk setiap tipe modulasi. Centriod ideal tersebut akan berbentuk diagram konstelasi sebagaimana terlihat pada gambar 2 .

\section{Pembangkitan data input}

Proses selanjutnya adalah membangkitkan sampel data input berupa elemen titik-titik simbol dalam konstelasi kuadran secara acak dengan fasa dan amplitudo yang bermacammacam.
3. Klasifikasi menggunakan Fuzzy C Means (FCM)

Dari sebaran data input tersebut, proses selanjutnya adalah klasifikasi data berdasarkan clustering menggunakan teknik Fuzzy C Means. Proses clustering ini nantinya akan menentukan titik centroid sebagai pusat dari tiap-tiap kelompok data dalam kuadran konstelasi.

4. Pengenalan pola modulasi menggunakan

\section{Template Matching}

Setelah menentukan centroid pada beberapa cluster yang terbentuk dari data input, maka proses selanjutnya yang merupakan proses terakhir yaitu pengenalan pola dari centroid yang dihasilkan. Pola-pola centroid tersebut disesuaikan atau dibandingkan dengan pola centroid ideal/standar yang telah ditetapkan lebih dahulu pada proses inisiasi awal. Teknik pengenalan pola yang dusulkan menggunakan Template Matching.

Secara ringkas, langkah-langkah tersebut ditunjukkan pada gambar 3 berikut ini:

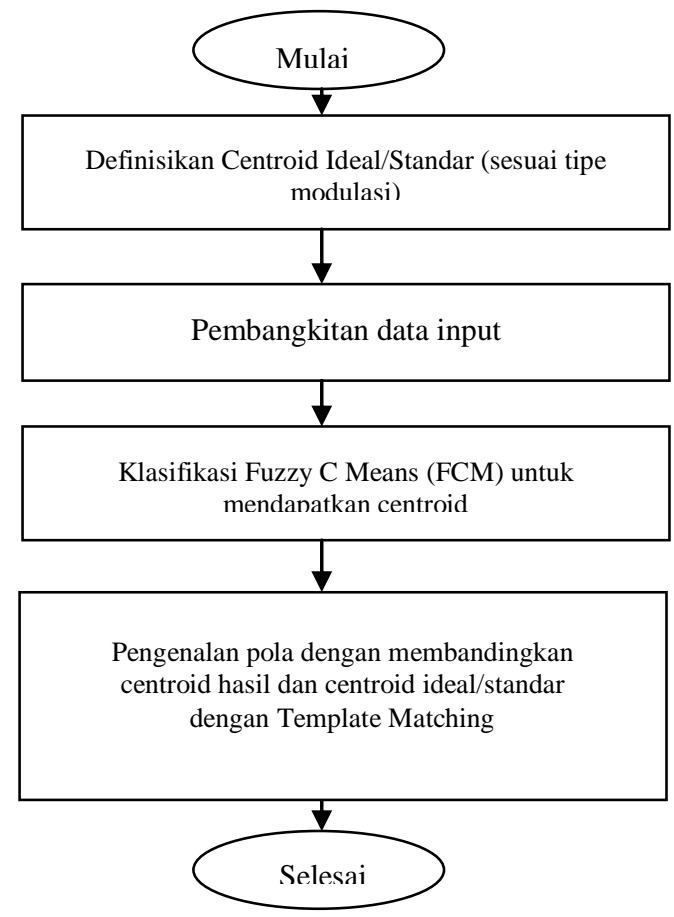


Gambar 3. Flowchart metode usulan penelitian

\section{HASIL DAN PEMBAHASAN}

\section{A. Pendefinisian Centriod Ideal/Standar}

Untuk menentukan jenis modulasi yang digunakan maka terlebih dahulu didefinisikan diagram konstelasi modulasi digital berdasarkan centroid ideal/standar yang akan dijadikan acuan.

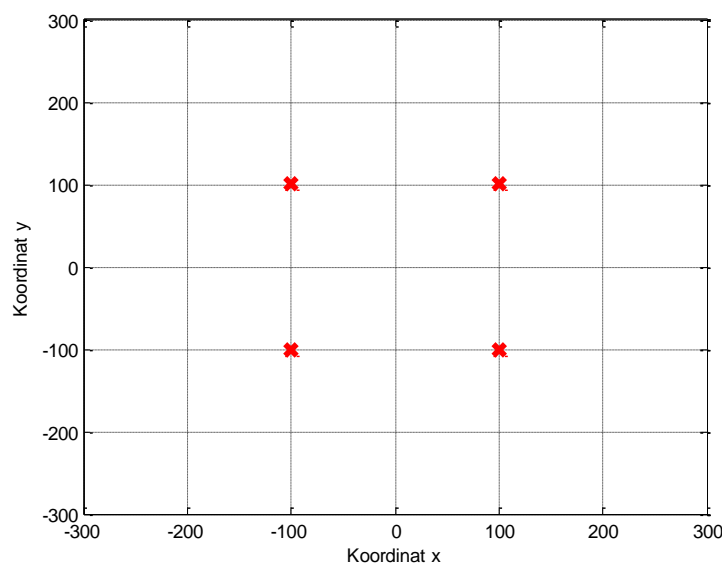

Gambar 4. Centriod ideal/standar untuk modulasi 4-QAM

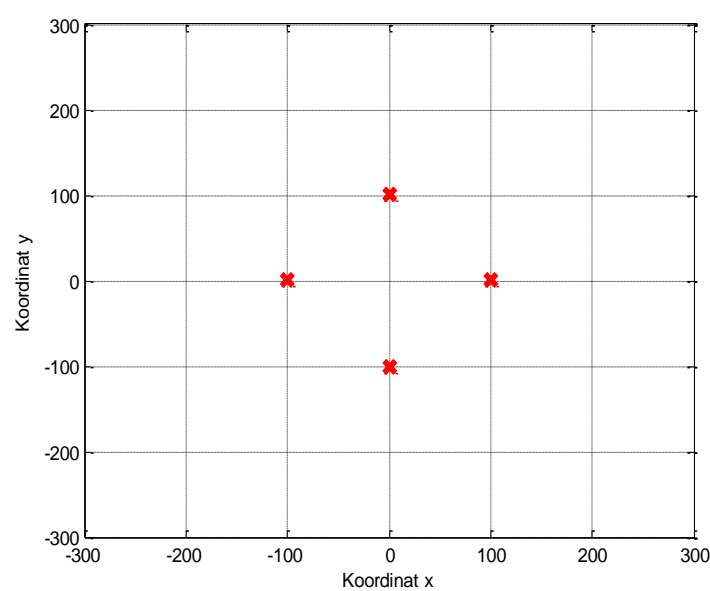

Gambar 5. Centriod ideal/standar untuk modulasi QPSK

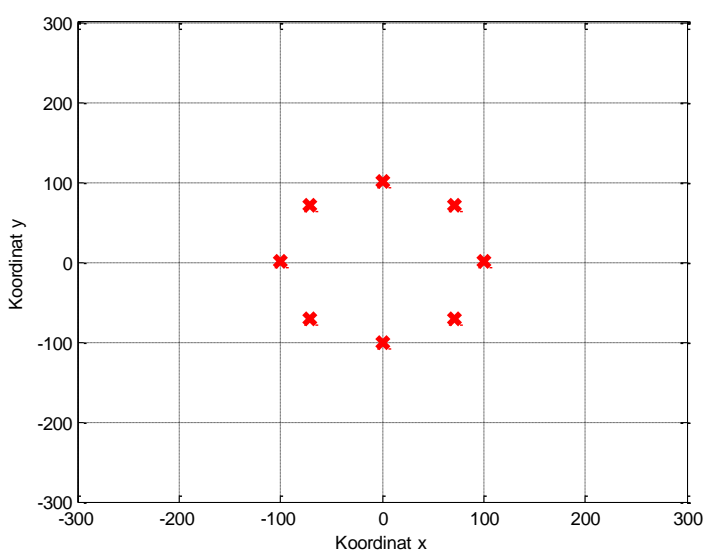

Gambar 6. Centriod ideal/standar untuk modulasi 8-PSK

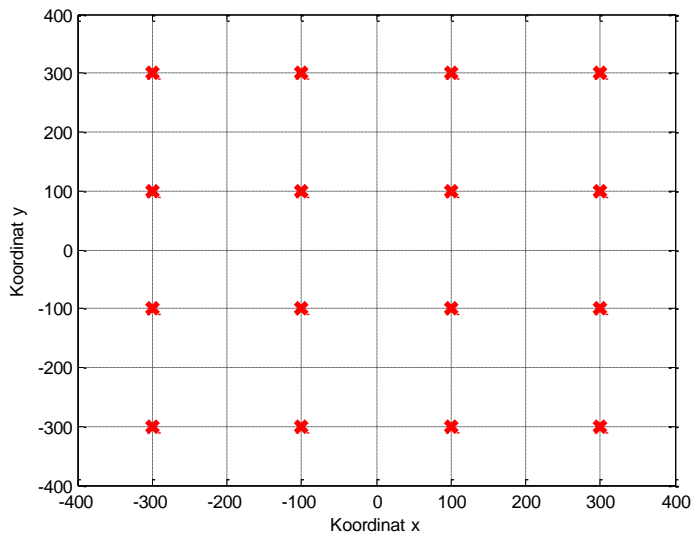

Gambar 7. Centriod ideal/standar untuk modulasi 16-QAM

\section{B. Pembangkitan Data Input}

Data yang dibangkitkan berupa titik-titk konstelasi yang menggambarkan jarak dari titik pusat $(0,0)$ sebagai amplitudo dan sudut di setiap kuadran sebagai fasa.

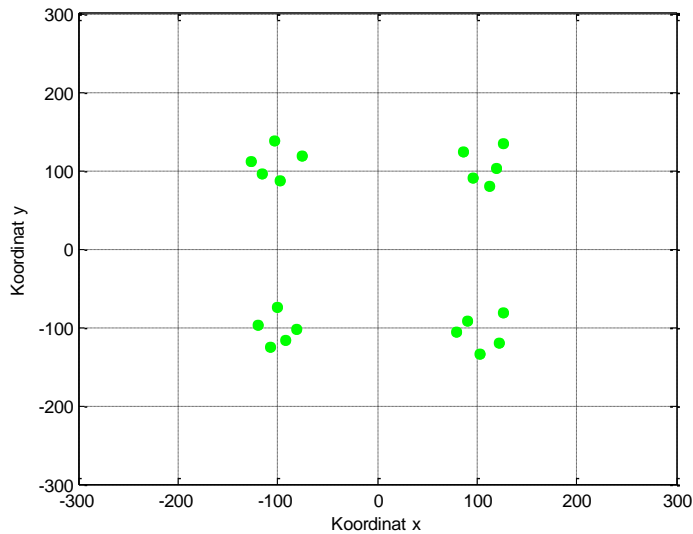

Gambar 8. Sebaran data untuk modulasi 4QAM 


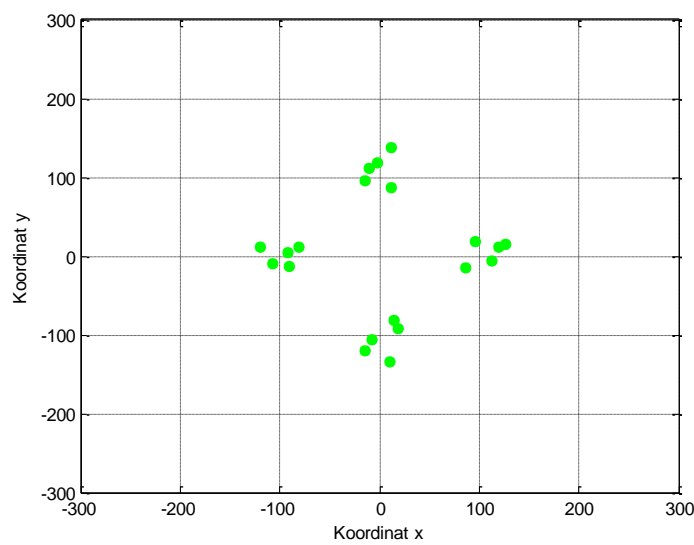

Gambar 9. Sebaran data untuk modulasi QPSK

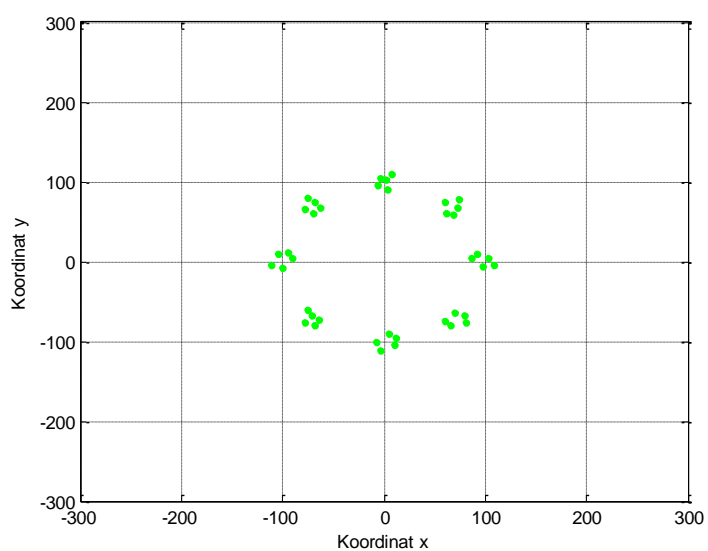

Gambar 10. Sebaran data untuk modulasi 8-PSK

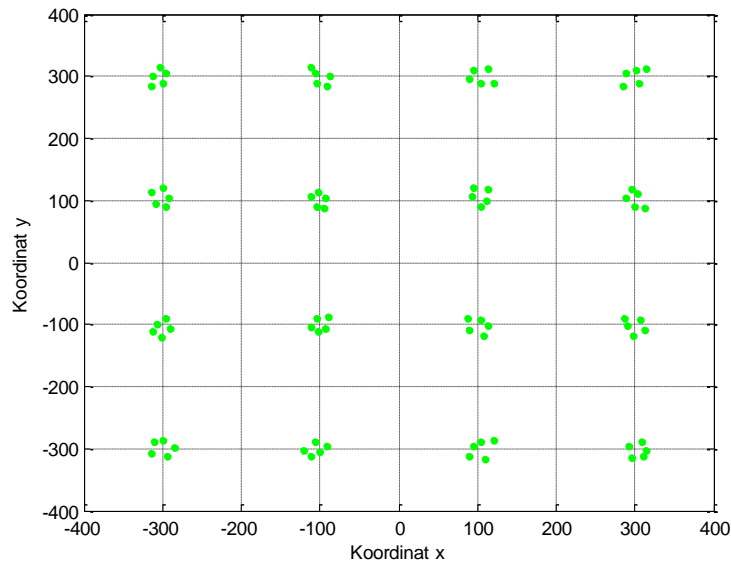

Gambar 11. Sebaran data untuk modulasi 16QAM

C. Klasifikasi menggunakan Fuzzy C Means $(F C M)$.

Dari sebaran data tersebut kemudian di klasifikasikan menggunakan Fuzzy C Means sehingga diperoleh centroid hasil clustering untuk setiap tipe modulasi yang ada. Gambar 12 sampai gambar 19 berikut adalah hasil dari proses clustering dalam rangka penentuan centroid berdasarkan FCM.

Setelah diperoleh hasil centroidnya maka proses selanjutnya adalah membandingkan antara centroid hasil dengan centroid ideal/standar kemudian ditentukan polanya berdasarkan template matching dengan menghitung mean selisih antara kedua centroid tersebut baik sumbu $\mathrm{x}$ maupun sumbu $\mathrm{y}$, sebagaimana terlihat pada Tabel 1 sampai Tabel 4.

\section{Hasil Clustering 4-QAM}

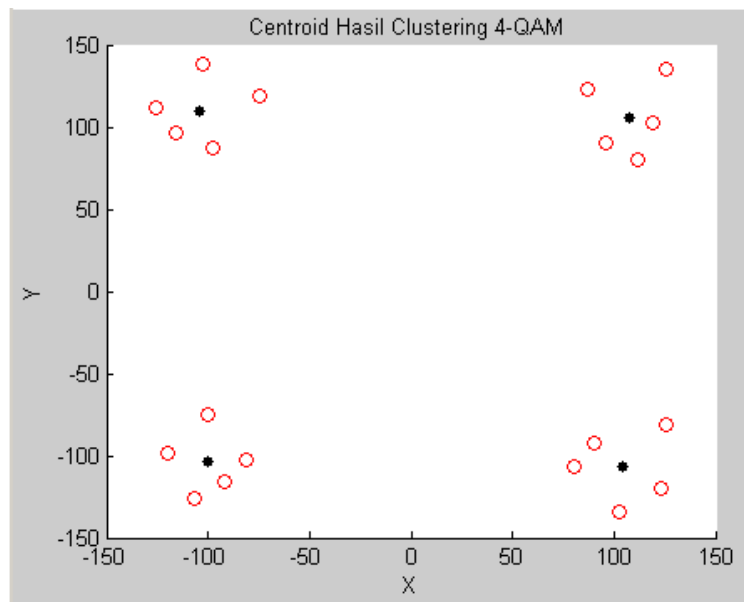

Gambar 12. Penentuan centroid modulasi 4QAM

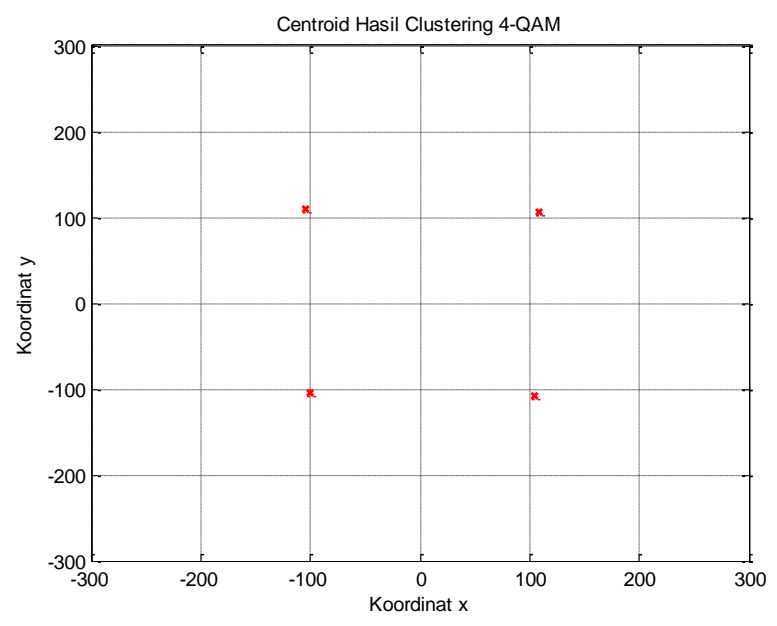

Gambar 13. Centroid hasil clustering 4-QAM 
TABEL 1.

PERBANDINGAN CENTROID 4-QAM

\begin{tabular}{|c|c|c|c|c|c|}
\hline \multicolumn{2}{|c|}{$\begin{array}{c}\text { Centroid } \\
\text { Ideal }\end{array}$} & \multicolumn{2}{c|}{$\begin{array}{c}\text { Centroid } \\
\text { Hasil }\end{array}$} & \multicolumn{2}{c|}{$\begin{array}{c}\text { Mean Selisih } \\
\text { Centroid }\end{array}$} \\
\cline { 1 - 4 } $\mathbf{x}$ & $\mathbf{y}$ & $\mathbf{x}$ & $\mathbf{y}$ & $\mathbf{x}$ & $\mathbf{y}$ \\
\hline 100 & -100 & 104,1521 & $-107,0436$ & & \\
\cline { 1 - 4 }-100 & 100 & $-103,941$ & 110,1877 & \multirow{2}{*}{4,0402} & 6,7750 \\
\cline { 1 - 4 } 100 & 100 & 107,9467 & 105,8747 & & \\
\cline { 1 - 4 }-100 & -100 & $-99,8792$ & $-103,9142$ & & \\
\hline
\end{tabular}

2. Hasil Clustering QPSK

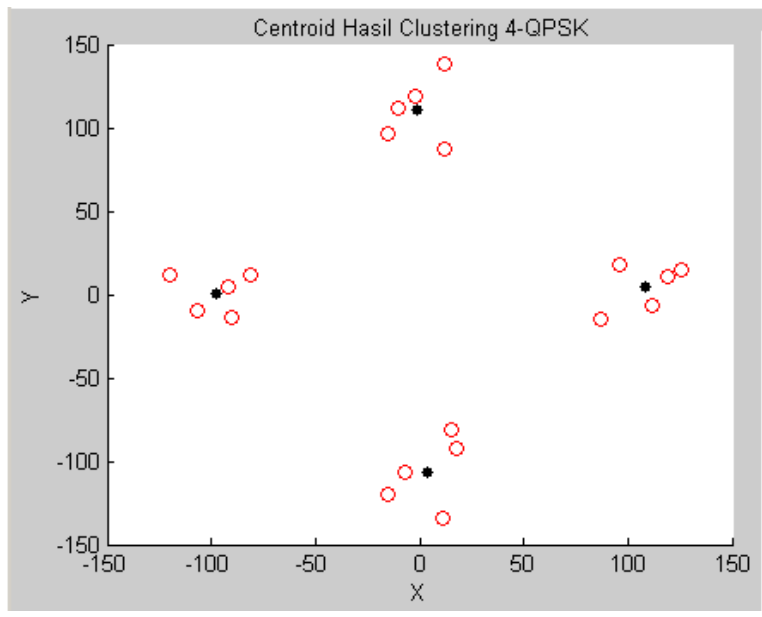

Gambar 14. Penentuan centroid modulasi QPSK

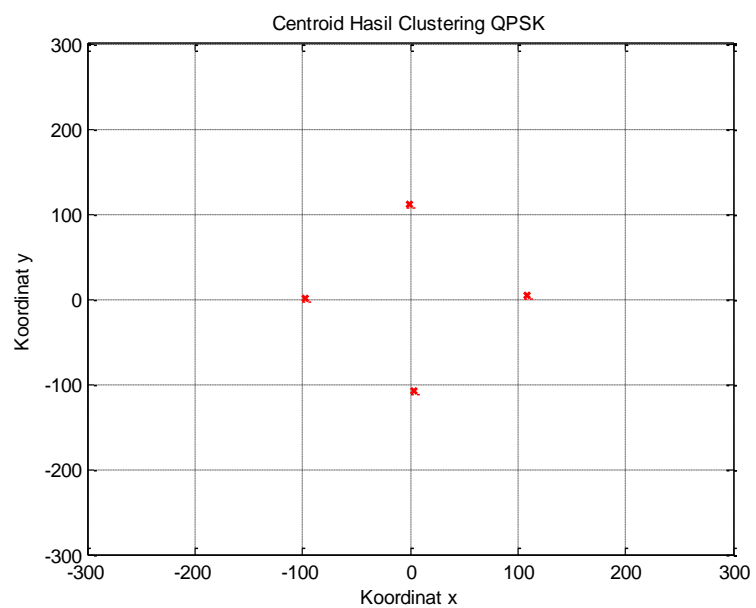

Gambar 15. Centroid hasil clustering QPSK

TABEL 2.

PERBANDINGAN CENTROID QPSK

\begin{tabular}{|c|c|c|c|c|c|}
\hline \multicolumn{2}{|c|}{$\begin{array}{c}\text { Centroid } \\
\text { Ideal }\end{array}$} & \multicolumn{2}{c|}{$\begin{array}{c}\text { Centroid } \\
\text { Hasil }\end{array}$} & \multicolumn{2}{c|}{$\begin{array}{c}\text { Mean Selisih } \\
\text { Centroid }\end{array}$} \\
\cline { 1 - 4 } $\mathbf{x}$ & $\mathbf{y}$ & $\mathbf{x}$ & $\mathbf{y}$ & $\mathbf{x}$ & $\mathbf{y}$ \\
\hline-100 & 0 & $-97,7651$ & 0,7970 & & \\
\cline { 1 - 4 } & -100 & 3,9785 & $-107,116$ & \multirow{3}{*}{3,9815} & 5,8528 \\
\cline { 1 - 4 } 100 & 0 & 108,5871 & 4,8778 & & \\
\hline 0 & 100 & $-1,1253$ & 110,6199 & & \\
\hline
\end{tabular}

\section{Hasil Clustering 8-PSK}

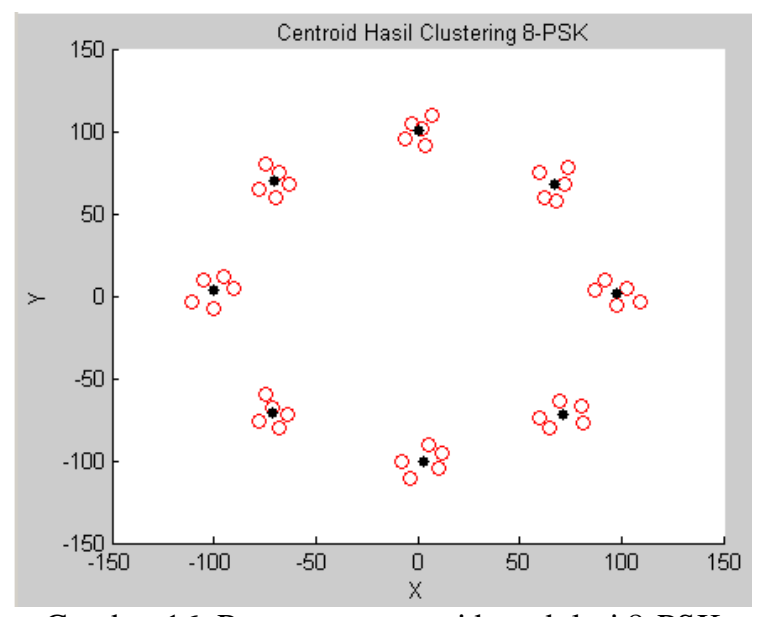

Gambar 16. Penentuan centroid modulasi 8-PSK

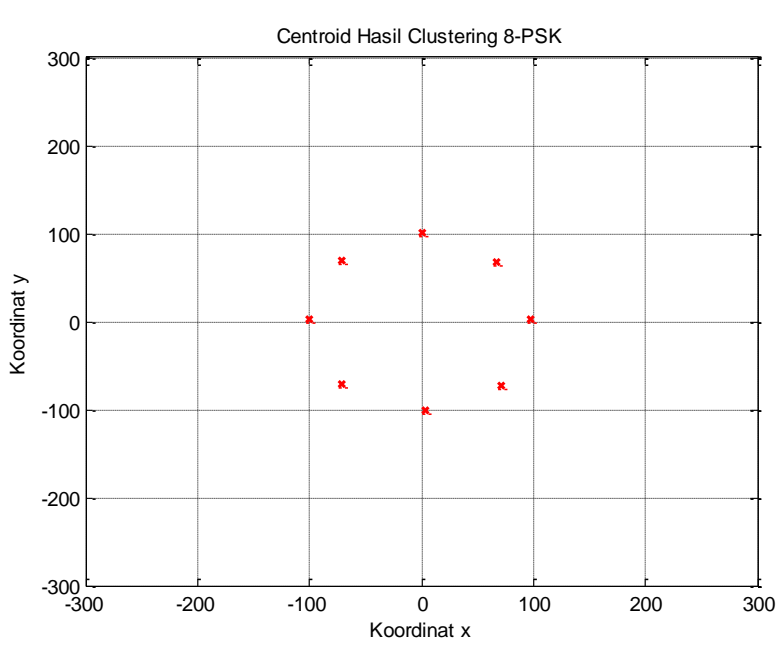

Gambar 17. Centroid hasil clustering 8-PSK

TABEL 3.

PERBANDINGAN CENTROID 8-PSK

\begin{tabular}{|c|c|c|c|c|c|}
\hline \multicolumn{2}{|c|}{$\begin{array}{l}\text { Centroid } \\
\text { Ideal }\end{array}$} & \multicolumn{2}{|c|}{$\begin{array}{c}\text { Centroid } \\
\text { Hasil }\end{array}$} & \multicolumn{2}{|c|}{$\begin{array}{l}\text { Mean Selisih } \\
\text { Centroid }\end{array}$} \\
\hline $\mathbf{x}$ & y & $\mathbf{x}$ & $y$ & $\mathbf{x}$ & $y$ \\
\hline 70,7107 & $-70,7107$ & 71,2517 & $-72,3278$ & \multirow{8}{*}{1,3285} & \multirow{8}{*}{1,5103} \\
\hline 100 & 0 & 97,8509 & 1,7906 & & \\
\hline$-70,7107$ & $-70,7107$ & $-71,1111$ & $-71,3022$ & & \\
\hline$-70,7107$ & 70,7107 & $-70,7276$ & 69,5809 & & \\
\hline 70,7107 & 70,7107 & 67,2314 & 67,6865 & & \\
\hline 0 & 100 & 0.7282 & 100,6460 & & \\
\hline-100 & 0 & $-100,1573$ & 3,1329 & & \\
\hline 0 & -100 & 3,1559 & $-100,1503$ & & \\
\hline
\end{tabular}


4. Hasil Clustering 16-QAM

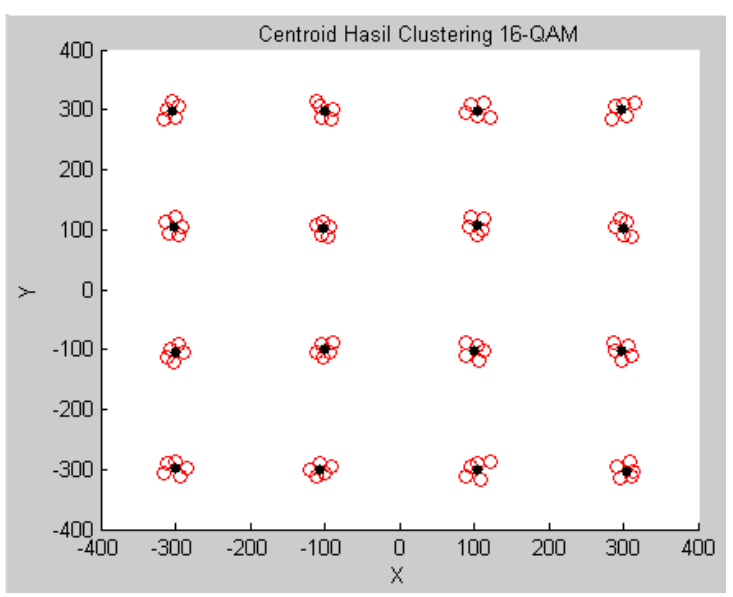

Gambar 18. Penentuan centroid modulasi 16QAM

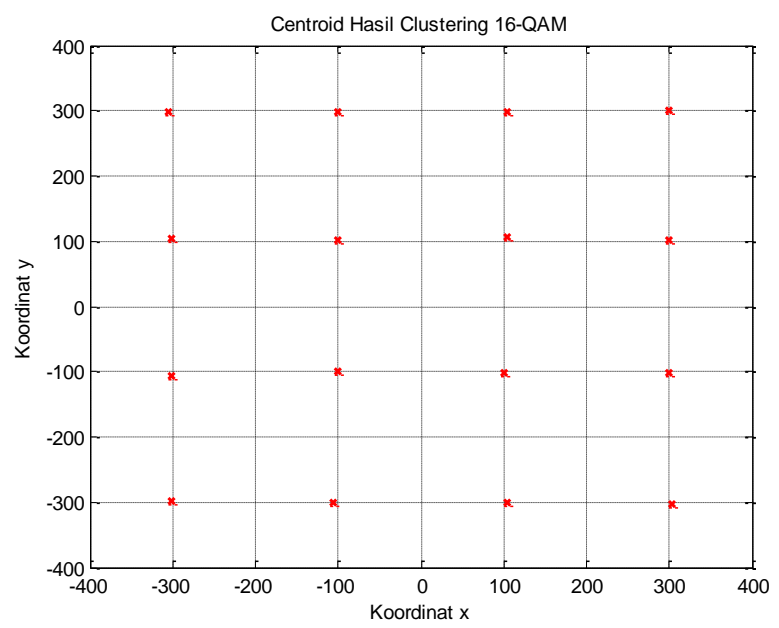

Gambar 19. Centroid hasil clustering 16-QAM

TABEL 4.

PERBANDINGAN CENTROID 16-QAM

\begin{tabular}{|c|c|c|c|c|c|}
\hline \multicolumn{2}{|c|}{ Centroid Ideal } & \multicolumn{2}{|c|}{$\begin{array}{c}\text { Centroid } \\
\text { Hasil }\end{array}$} & \multicolumn{2}{|c|}{$\begin{array}{l}\text { Mean Selisih } \\
\text { Centroid }\end{array}$} \\
\hline $\mathrm{x}$ & y & $\mathbf{x}$ & y & $\mathbf{x}$ & y \\
\hline 300 & 100 & 299,6887 & 102,9052 & \multirow{16}{*}{2,2754} & \multirow{16}{*}{2,2525} \\
\hline-300 & 300 & $-305,1646$ & 298,8202 & & \\
\hline-100 & -100 & $-100,2477$ & $-100,5051$ & & \\
\hline 100 & -300 & 103,7496 & $-300,3346$ & & \\
\hline-100 & 300 & $-100,3614$ & 298,7251 & & \\
\hline 300 & 300 & 298,8496 & 300,5342 & & \\
\hline-300 & -100 & $-301,0355$ & $-105,8188$ & & \\
\hline-300 & 100 & $-301,9773$ & 104,9545 & & \\
\hline 300 & -100 & 298,8296 & $-102,2153$ & & \\
\hline 300 & -300 & 304,0554 & $-302,8590$ & & \\
\hline-300 & -300 & $-300,8289$ & $-298,7283$ & & \\
\hline-100 & 100 & $-101,1818$ & 100,8281 & & \\
\hline 100 & 300 & 104,8433 & 298,8204 & & \\
\hline 100 & 100 & 103,5898 & 106,9533 & & \\
\hline 100 & -100 & 100,9251 & $-102,1907$ & & \\
\hline-100 & -300 & $-105,8141$ & $-301,0358$ & & \\
\hline
\end{tabular}

D. Pengenalan Pola Menggunakan Template Matching

Dengan membandingkan antara centroid ideal/standar dan centroid hasil clustering maka akan diperoleh tingkat kecocokan berdasarkan pengenalan pola. Teknik yang digunakan pada pengenalan pola disini adalah menggunakan Template Matching, dimana metodenya adalah dengan menghitung mean (rerata) dari selisih antara centroid ideal dengan centroid hasil. Jika rerata selisihnya kurang dari 25\% (atau tingkat kecocokannya lebih dari 75\%) maka pola tersebut dikenali atau dengan kata lain modulasinya cocok. Hasilnya menunjukkan tingkat kecocokan yang tinggi pada semua tipe modulasi yang digunakan yaitu rata-rata diatas $95 \%$, sebagaimana diperlihatkan pada tabel 5 berikut ini:

TABEL 5.

HASIL PENCOCOKAN POLA

\begin{tabular}{|c|c|c|c|c|c|}
\hline JENIS & \multicolumn{2}{|c|}{$\begin{array}{c}\text { MEAN SELISIH } \\
\text { CENTROID }\end{array}$} & \multicolumn{2}{|c|}{$\begin{array}{c}\text { TINGKAT } \\
\text { KECOCOKAN }\end{array}$} & \multirow{2}{*}{ KET } \\
\cline { 1 - 5 } MODULASI & $\mathbf{x}(\%)$ & $\mathbf{y}(\%)$ & $\mathbf{x}(\%)$ & $\mathbf{y}(\%)$ & \\
\hline 4-QAM & 4,0402 & 6,7550 & 95,9598 & 93,2450 & COCOK \\
\hline QPSK & 3,9815 & 5,8528 & 96,0185 & 94,1472 & COCOK \\
\hline 8-PSK & 1,3285 & 1,5103 & 98,6715 & 98,4897 & COCOK \\
\hline 16-QAM & 2,2754 & 2,2525 & 97,7246 & 97,7475 & COCOK \\
\hline
\end{tabular}

\section{IV.PENUTUP}

Berdasarkan hasil pengenalan pola menggunakan template matching, hasilnya menunjukkan tingkat kecocokan yang tinggi pada semua tipe modulasi yang digunakan yaitu rata-rata diatas 95\%, yang menunjukkn bahwa pola tersebut dikenali atau dengan kata lain modulasinya cocok. 


\section{DAFTAR PUSTAKA}

[1] Negar Ahmadi \& Reza Berangi, "Symbol Based Modulation Classification using Combination of Fuzzy Clustering and Hierarchical Clustering", An International Journal (SPIJ), Volume (4) : Issue (2)

[2] Negar Ahmadi \& Reza Berangi, “A Template Matching Approach to Classification of QAM Modulation using Genetic Algorithm", An International Journal (SPIJ) Volume (3): Issue (5) 